\title{
REFORMASI DK PBB: ANTARA KEPENTINGAN NASIONAL, REGIONAL, DAN GLOBAL/BERSAMA
}

\author{
Luerdi \\ Mahasiswa Pascasarjana Ilmu Politik Universitas Riau
}

\section{Citation as}

Luerdi, L. (2014). Reformasi DK PBB: Antara Kepentingan Nasional, Regional, dan Global/Bersama. https://doi.org/10.31219/osf.io/9kt6d 


\title{
Reformasi DK PBB: Antara Kepentingan Nasional, Regional, dan Global/Bersama ${ }^{1}$
}

\author{
Luerdi \\ Mahasiswa Pascasarjana Ilmu Politik Universitas Riau
}

Salah satu agenda global yang masih belum menemui 'bentuk akhir' nya adalah reformasi Dewan Keamanan (DK) PBB. Upaya ini merupakan bagian dari wacana reformasi PBB. Mereformasi PBB tidak memiliki arti bila tidak mereformasi DK PBB karena badan ini memiliki peran ekslusif dalam menentukan dan membentuk politik dunia dibalik wewenangnya memelihara perdamaian dan keamanan dunia.

Badan ini bisa dikatakan sebagai klub elit dan misterius dibandingkan badan-badan lain dalam organisasi PBB. Elit karena lima negara anggota tetap yang sering disebut $\mathrm{P}_{5}$ memiliki hak veto dan mendominasi pembuatan kebijakan, misterius karena kurangnya transparansi dalam pembuatan kebijakan sementara kebijakan yang dikeluarkan oleh DK bersifat mengikat bagi seluruh anggota PBB.

Tuntutan reformasi DK PBB muncul sebagai upaya untuk menjadikan institusi global PBB lebih demokratis dan representatif sesuai dengan perkembangan politik dunia. DK PBB dianggap terlalu Europecentic dan mengesampingkan aspirasi negara-negara di Selatan. Tuntutan ini sesuai dengan perkembangan dimana politik dunia abad ke-21 tidak lagi sama dengan era pasca Perang Dunia II. Kofi Annan (2003) pernah mengungkapkan reformasi DK PBB diperlukan untuk menjadikan badan tersebut efektif dan representatif berdasarkan realitas geopolitik abad ke-21. ${ }^{2}$ Isu-isu politik berkaitan dengan perdamaian dan keamanan seharusnya tidak lagi hanya ditentukan oleh great powers pemenang PD II, tapi melibatkan negara-negara di belahan benua lain. 
Justin Morris berpendapat karakter DK PBB menunjukkan ketidakseimbangan. Ini dikarenakan keberadaan negara-negara anggota tetap DK dengan hak veto tidak mencerminkan aspirasi mayoritas negara anggota PBB khususnya dalam penggunaan kekerasan (force) dalam merespon ancaman. ${ }^{3}$ DK PBB sering kali dianggap hanya sebagai wadah politik nasional negara-negara kuat. Selanjutnya Morris mengatakan bahwa pasca Perang Dingin keberadaan dan keefektifan DK PBB semakin mendapatkan kritikan dan menghadapi krisis legitimasi seiring dengan tampilnya Amerika Serikat (AS) sebagai the only super power politik dunia. AS menjadi hegemon dan terlalu mendominasi DK, dan DK pun tidak mampu menghambat kecenderungan tindakan unilateralisme AS dalam menggunakan kekerasan. ${ }^{4}$

Komposisi awal DK PBB setelah ratifikasi San Fransisco Charter diisi oleh negara-negara pemenang Perang Dunia II (Amerika Serikat, Uni Soviet/Rusia, Cina/PRC, Inggris dan Perancis) dan enam anggota tidak tetap (Australia, Brazil, Mesir, Meksiko, Belanda, dan Polandia). ${ }^{5}$ Tuntutan mereformasi DK PBB pertama muncul pada tahun 1956 dari negara-negra Amerika Latin mengingat kala itu banyak negara-negara yang baru merdeka dan menjadi anggota PBB. Pada tahun 1965, komposisi DK PBB berubah menjadi 15 seperti saat ini setelah diratifikasi oleh 2/3 anggota PBB. ${ }^{6}$ Jumlah anggota tidak tetap DK bertambah menjadi 10 sedangkan tidak ada perubahan pada anggota tetap (P5).

Sejak tahun 1993, tuntutan reformasi DK PBB kembali muncul dengan proposal yang bervariasi baik dari negara dan kelompok negara (regional) dengan penekanan isu yang lebih luas tidak hanya mengenai jumlah keanggotaan, tapi juga menyangkut legitimasi hak veto, transparansi, dan cara kerja (working method). Ada kesepahaman mayoritas negara khususnya pada negara-negara dunia ke-tiga bahwa reformasi DK PBB menjadi kebutuhan untuk menjadikan badan tersebut lebih demokratis dan representatif. Namun kesepahaman tersebut tidak mampu membawa progress yang signifikan bagi reformasi DK PBB sampai saat ini. 
Tidak adanya konsensus terhadap proposal model reformasi DK PBB yang diajukan walaupun terdapat kesepahaman perlunya mereformasi DK PBB menjadi penyebab utama kemandegan gagasan reformasi tersebut. Negaranegara sangat sulit untuk menyamakan persepsi tentang model DK PBB yang ideal. Negara-negara dan kelompok negara memperjuangkan proposalnya masing-masing karena didalamnya terdapat kepentingan nasional negara dan kelompok negara tersebut.

Misalnya pada tahun 2008-2009, blok Group of Four yang dikenal dengan G-4 yang terdiri dari Jerman, Brazil, India dan Jepang mengajukan diri untuk menjadi anggota tetap DK PBB. Jerman dan Jepang adalah penyumbang signifikan bagi dana PBB, India adalah negara demokrasi terbesar di dunia dan juga kekuatan nuklirnya sedang meningkat, sedangkan Brazil adalah negara ekonomi terbesar di Amerika Selatan. Keinginan G-4 tidak mendapatkan dukungan yang luas dan ditentang khususnya oleh negaranegara rival kawasan mereka yang dikenal dengan blok Uniting for Consensus seperti Italia, Argentina, Pakistan, Korea Selatan dan negara lainya.7

Organization of African Union (OAU) dan organisasi negara Non-Blok (NAM) juga pernah menawarkan proposal reformasi DK PBB. OAU mengusulkan perluasan keanggotaan DK PBB berdasarkan keterwakilan regional baik untuk anggota tetap ataupun anggota tidak tetap. Berdasarkan Harare Declaration, OAU mengusulkan jumlah keanggotaan DK PBB menjadi sebanyak 26 negara, dimana setidaknya 2 anggota tetap dan 5 anggota tidak tetap berasal dari Afrika. Selanjutnya keanggotaan anggota tetap dari Afrika akan ditentukan sendiri oleh mekanisme OAU dengan sistem rotasi dengan kriteria yang ditetapkan oleh internal organisasi tersebut. ${ }^{8}$ Dalam proposal yang diajukan, OAU lebih banyak menguraikan keterwakilan Afrika dan tidak menjelaskan lebih lanjut tentang bagaimana mekanisme keterwakilan regional lainnya. 
Gerakan negara Non-Blok (NAM) juga mengusulkan jumlah keanggotan DK PBB tidak kurang dari 26 seperti yang diusulkan oleh OAU. Namun NAM tidak hanya mengusulkan perluasan berdasarkan distribusi geografis yang seimbang, tapi juga kesetaraan kedaulatan negara-negara. ${ }^{9}$ Bagi NAM, DK PBB tidak ubahnya seperti badan neo-kolonialist atau neo-imperialist. NAM tidak menyetujui usulan penambahan keanggotan DK PBB yang bersifat selektif dan cenderung istimewa kepada negara-negara tertentu. Penolakan NAM ini menunjuk pada keinginan Jerman dan Jepang untuk menjadi anggota tetap DK PBB hanya karena berstatus negara maju dan penyumbang dana bagi PBB. Namun - seperti yang dikatakan Morris - usulan NAM bersifat umum, tidak spesifik seperti usulan OAU sehingga bentuknya menjadi kabur. ${ }^{10}$ Selanjutnya NAM menginginkan perubahan mengenai hak istimewa veto, dimana veto seharusnya dihapuskan atau diperluas kepada semua anggota tetap yang baru. ${ }^{11}$

Baik usulan OAU dan NAM tidak menarik bagi negara-negara Eropa yang lebih menginginkan perubahan yang terbatas dan selektif dalam DK PBB. Bagi negara-negara maju Eropa, perluasan keanggotan DK PBB hanya akan mempersulit pengambilan kebijakan dan membuat DK menjadi badan yang tidak efektif. Efektifitas DK PBB dapat dicapai bila badan tersebut ramping atau diperluas secara terbatas dan selektif. Eropa menginginkan DK PBB seharusnya diisi utamanya oleh negara-negara maju yang secara ekonomi, politik dan militer kuat.

Adanya kecenderungan anggota tetap (P5) mempertahankan dominasi pembuatan kebijakan dan eksklusifitas hak veto pada DK PBB juga berkontribusi pada ketidakberhasilan upaya untuk mereformasi badan tersebut. Wacana penambahan anggota DK PBB baik anggota tetap dan tidak tetap ataupun wacana peniadaan, penambahan dan pengurangan hak veto menjadi isu yang sensitif bagi P5. P5 sangat berhati-hati dalam merespon 
keinginan reformasi PBB yang dapat mengurangi bahkan menghilangkan ‘keistimewaan' mereka pada badan tersebut.

Melihat kenyataan diatas, negara-negara baik secara sendiri-sendiri ataupun secara kolektif (regional) berupaya untuk menjalankan politik luar negerinya terkait tuntutan reformasi DK PBB. Setiap negara khususnya the rising country memiliki kepentingan nasional yang berbeda dibalik reformasi DK PBB. Benturan kepentingan nasional negara-negara dapat dilihat dari beragamnya model reformasi PBB yang sulit untuk disatukan. Tidak hanya antara blok negara maju vis a vis blok negara dunia ke-tiga, tapi juga antar negara-negara dunia ke-tiga dan antar negara-negara maju itu sendiri.

Model yang diajukan oleh OAU dengan jelas menampilkan kepentingan regional Afrika. Negara-negara Afrika ingin memainkan peran yang besar dalam pembuatan kebijakan DK PBB khususnya bila isu-isu yang dibicarakan berkaitan dengan keamanan dan perdamaian di kawasan tersebut. Namun organisasi kawasan Afrika tersebut juga menggariskan pentingnya keterwakilan negara-negara yang berasal dari kawasan lain. Model reformasi DK PBB yang diusulkan oleh OAU merupakan model yang paling fair yang dapat mewakili semua negara berdasarkan representasi kawasan. Namun proposal ini tidak mendapatkan dukungan yang berarti dari $\mathrm{P}_{5}$.

Kepentingan global/bersama untuk mewujudkan DK PBB yang demokratis dan representatif akan berbenturan dengan kepentingan P5. Kepentingan nasional negara-negara P5 dalam DK PBB akan menjadi lapisan dinding penghalang paling dalam untuk mereformasi badan tersebut. Sejak wacana reformasi DK PBB digulirkan, P5 tidak memberikan dukungan yang kuat untuk mereformasi DK PBB. P5 dengan hak veto yang dimiliki sudah merasa nyaman dengan sistem yang ada. Selain itu, berdasarkan Piagam PBB reformasi DK PBB dapat dilakukan bila adanya persetujuan 2/3 dari seluruh anggota PBB termasuk didalamnya P5. 
Kalaupun negara P5 memberikan dukungan pada negara tertentu untuk masuk dalam keanggotaan DK PBB, dukungan tersebut terkesan sekedar menampakkan wujud partisipasi dalam isu global ini. Misalnya, AS mengapresiasi keinginan India sebagai anggota tetap dan Perancis mendukung satu kursi anggota tetap untuk Afrika. ${ }^{12}$ Namun belum tampak tindak lanjut dan komitmen dari sikap politik tersebut.

Selain G-4, blok Uniting for Consensus, OAU dan NAM, kelompok negara kecil yang dikenal dengan S-5 (Costa Rica, Jordania, Lichtenstein, Singapura dan Swiss) juga mengajukan proposal reformasi DK PBB. Namun S-5 cenderung mengangkat isu transparansi dan koordinasi antara DK PBB dan Majelis Umum PBB dan Komite Ekonomi dan Sosial PBB. Proposal tersebut juga memasukkan beberapa panduan terhadap penggunaan hak veto. ${ }^{13}$ Kofi Annan (2005) sebagai Sekretaris PBB kala itu juga mengusulkan model reformasi DK PBB yang dikenal dengan Model A dan Model B. Namun model yang diajukan Annan tersebut tidak didukung oleh semua faksi di PBB. ${ }^{14}$

Upaya mereformasi DK PBB hanya akan menjadi sebuah utopia bila negara-negara tidak memiliki persepsi yang sama terhadap model reformasi yang diinginkan. Negara-negara seharusnya mengesampingkan ambisi nasional masing dan fokus pada kepentingan bersama untuk menjadikan DK PBB sebagai institusi global yang demokratis, transparan dan representatif. Seperti yang ditulis oleh Justin Morris dan Nicholas J. Wheeler (2007), DK PBB merupakan jantung dari sistem keamanan kolektif. ${ }^{15}$ DK PBB seharusnya tidak hanya menjadi tempat berhuninya dominasi dan hegemoni great powers.*

\section{Referensi}

${ }^{1}$ Bahan diskusi perkuliahan pada Program Studi Ilmu Politik Pascasarjana Universitas Riau (2013-2014).

${ }^{2}$ Ranjan Roy (2003: Annan Seeks Expanded UN Security Council), dikutip oleh Maria Mikhailtchenko., 2004, Reform of the Security Council and Its 
Implications for Global Peace and Security, dalam Journal of Military and Strategic Studies, Fall 2004, Vol. 7, hal. 1.

3 Justin Morris dan Nicholas J. Wheeler., 2007, The Security Council's Crisis of Legitimacy and the Use of Force, dalam Jornal of International Politics, 2007, 44, hal. 214 .

4 lbid.,

5 The UN Security Council, http://www.unfoundation.org/what-we-

do/issues/united-nations/the-un-security-council.html, diakses o6 Mei 2014.

${ }^{6}$ Maria Mikhailtchenko., Op.Cit., hal. 2.

7 http://www.globalpolicy.org/security-council/security-council-reform/47966-

security-council-reform-page-with-documents-2009.html, diakses o6 Mei 2014.

${ }^{8}$ Harare Declaration of the Assembly of Heads of State and Government of the Organization of African Unity on the Reform of the United Nations Security Council, dikutip oleh Justin Morris, 2003, The United Nations Security Council: Prospects for Reform, Lecture delivered at the Dennison Centre of University of Hull England, hal.15, http://www2.hull.ac.uk/fass/pdf/Lawmccoubreylecture03. pdf diakses 06 Mei 2014.

9 Document of the XIIth Summit of the Non-Aligned Movement, 2-3 September 1998, Durban, South Africa, dikutip oleh Justin Morris, Ibid., hal. 16. 10 Ibid., hal. 15.

${ }^{11}$ Ibid., hal. 16.

${ }^{12}$ Background on Security Council Reform, http://www.globalpolicy.org/security-council/security-councilreform/49885.html?itemid=1321, diakses 06 Mei 2014.

13 Ibid.,

14 Ibid.,

15 Justin Morris dan Nicholas J. Wheeler., Opcit., 